\title{
CLENICAL POLITICAL IMPLICATIONS IN WOMEN'S POLITICAL PARTICIPATION AT KAILI COMMUNITIES IN THE PALU VALLEY
}

\author{
Nisbah \\ Universitas Tadulako,nisbabb7@gmail.com
}

\begin{tabular}{l|l|l} 
Diterima: 29 Januari 2019 & Direvisi :14 Mei 2019 & Diterbitkan: 30 Juni 2019
\end{tabular}

\begin{abstract}
One of the phenomena in political reality that emerged after the new era was the strengthening of political clen in local communities who still relied on genealogic relations. In an effort to encourage the inclusion of women in the political process, klen political tendencies have degraded the spirit of increasing women's political participation. Women's political participation in socio-political institutions in local communities will be based on genealogic factors. In the Kaili community in the Palu Valley, for example, the increase in women's political participation was formed because women came from the dominant clan and still bound in a fraternal bond with the functionaries of political parties and other political institutions so that they were easily involved in the political process. Genealogic relationship between female members of the dominant klen and the leader and central figure of the dominant clen gives space for women's participation in politics. The dominant clen genealogically is related to kinship relations with the aristocratic group who once had autbority during the royal government. The distribution of the dominant role of klen women in strategic positions in socio-political institutions is directed to strengthen the reach of klen's interests in political power. The implication of klen's role in women's political participation increases the recruitment of dominant clen women members in number but the role in institutional activities is precisely reduced and weakened.
\end{abstract}

Keywords: Clenical Political Implication, Women Political Participation, Kaili Communities, Palu Valley

\begin{abstract}
Abstrak
Salah satu fenomena dalam realitas politik yang muncul setelah masa Orde Baru adalah menguatnya politik klen pada masyarakat lokal yang masih mengandalkan hubungan genealogik. Dalam upaya mendorong pelibatan perempuan dalam proses politik, kecenderungan politik klen telah mendegradasi semangat peningkatan partisipasi politik perempuan. Partisipasi politik perempuan dalam lembaga sosial politik pada masyarakat lokal akan didasarkan pada faktor genealogik. Pada masyarakat Kaili di Lembah Palu misalnya, meningkatnya partisipasi politik perempuan terbentuk karena perempuan berasal dari klen dominan dan masih terikat dalam satu ikatan persaudaraan dengan fungsionaris parpol dan lembaga politik lainnya sehingga mudah terlibat pada proses politik. Hubungan genealogik antara perempuan anggota klen dominan dengan pemimpin dan tokoh sentral klen dominan memberi ruang partisipasi perempuan dalam politik. Klen dominan secara genealogik terkait hubungan kekerabatan dengan golongan bangsawan yang pernah memiliki kekuasaan adat pada masa pemerintahan kerajaan. Distribusi peran perempuan klen dominan pada posisi strategik di lembaga sosial politik diarahkan untuk memporkokoh jangkauan kepentingan klen dalam kekuasaan politik. Implikasi peranan klen dalam partisipasi politik perempuan meningkatkan rekruitmen perempuan anggota klen dominan secara jumlah namun peran dalam kegiatan lembaga justeru tereduksi dan melemah.
\end{abstract}

Kata Kunci: Implikasi Politik Klen, Partisipasi Politik Perempuan, Masyarakat Kaili, Lembah Palu.. 


\section{Latar Belakang}

Salah satu isu politik yang penting dalam melihat fenomena partisipasi politik saat ini adalah adanya politik klen atau politik kekerabatan. Setelah berakhirnya otoritarianisme Orde Baru, sebuah gejala baru muncul dalam kehidupan politik Indonesia, yakni menguatnya klen atau kekerabatan dalam politik (kinship politics) . Fenomena tersebut cenderung ditemukan dalam realitas politik lokal, yang ditandai dengan penguasaan posisiposisi penting dalam kelembagaan sosial politik seperti pemerintahan, legislatif, partai politik dan organisasi kemasyarakatan yang lazim didominasi oleh mereka yang berada dalam satu garis keturunan yang sama. Politik klen dalam tinjauan analisis politik seringkali dianalogikan dengan politik kekerabatan atau politik dinasti. Politik klen dalam bentuknya tampil serupa dengan politik kekerabatan yang mengandalkan jaringan kekerabatan sebagai mekanisme untuk memperkuat akses politik sekaligus akses ekonomi dalam proses politik.

Menguatnya politik klen atau politik kekerabatan yang terjadi menggambarkan bahwa struktur budaya tradisional kental mewarnai proses politik yang terjadi pada masyarakat lokal yang cenderung masih menggenggam nilai-nilai budaya kesukuan. Pada konteks tersebut, politik klen didefenisikan sebagai proses budaya untuk memelihara geneologi politik dan mengukuhkan dinasti politik dengan kepentingan menjaga dinasti kekuasaan dan keberlangsungan karir politik. Dengan demikian akses-akses ekonomi yang ada juga dapat ikut diwariskan dan didistribusikan kepada keluarga dan kerabatnya.

Dalam politik klen terdapat upaya untuk mengekalkan dan melembagakan keberadaan klen atau satuan kekerabatan tertentu dalam proses politik yang terjadi.
Dalam realitas politik kecenderungan ini mengarah pada terbentuknya ketidak setaraan distribusi kekuasaan politik sebagai refleksi dari tidak sempurnanya sistem demokrasi yang diterapkan karena sesungguhnya sifat alamiah politik klen adalah kekuasaan yang hendak dijalankan secara turun-temurun berdasarkan garis keturunan yang ditarik secara genealogik.

Eksistensi klen sebagai kelompok keturunan dalam sistem kekerabatan masyarakat yang membentuk solidaritas genealogik juga menyediakan ruang dalam pelibatan perempuan secara politik. Realitas politik yang terjadi menggambarkan bahwa peranan klen juga turut menentukan proses partisipasi politik perempuan pada kelembagaaan sosial politik. Pilihan perempuan dalam proses partisipasi politik dapat terbentuk karena adanya hubungan genealogik dengan figur-figur sentral yang menjadi pemimpin ataupun tokoh penting dalam kelembagaan sosial politik sekaligus juga berasal dari klenklen yang ada. Keberlanjutan karir dan kedudukan perempuan pada proses Politik sangat bergantung pada kepemimpinan klen yang berkuasa. Kehadiran perempuan dalam proses politik belum sepenuhnya merupakan keputusan atas pilihan politik independen dan berorientasi pada upaya meningkatkan sumber daya.Tokoh-tokoh sentral yang memegang posisi kunci sebagai pemimpin dalam kelembagaan sosial politik ataupun lembaga pemerintah yang berasal dari klen yang ada dianggap akan mampu mengatur dan mengendalikan secara penuh kebijakan kelembagaan politik. Konsekwensi ini akan memberi pengaruh terhadap berjalannya proses regenerasi dalam klen termasuk bagi perempuan anggota klen untuk terlibat dalam mengisi ruang-ruang politik yang tersedia melalui partisipasi politik yang terjadi. 


\section{Partisipasi Politik Perempuan Di Lembah Palu}

Partisipasi politik perempuan pada hakekatnya adalah usaha untuk menggali dan memberdayakan potensi sumber daya yang dimiliki oleh perempuan sebagai makhluk sosial. Partisipasi politik bermakna pada keaktifan dan keikutsertaan perempuan tidak hanya dalam arti politik semata tetapi di dalam seluruh kehidupan yang berkaitan dengan keberadaan perempuan sebagai warga negara yang memiliki hak dan kewajiban yang harus dijalankan. Pentingnya partisipasi politik perempuan saat ini telah menjadi kebutuhan dalam rangka mengintegrasikan kepentingan dan kebutuhan perempuan dalam kehidupan bernegara.

Ani Soetjipto ${ }^{1}$ menyatakan bahwa kebijakan pemberdayaan perempuan harus berakselerasi dengan peningkatan partisipasi politik perempuan terutama dalam kegiatankegiatan politik formal. Peningkatan partisipasi politik perempuan bukan diarahkan pada upaya-upaya untuk meningkatkan jumlah perempuan di dunia politik, namun juga memperbaiki kinerja dan keberhasilan perempuan dalam berpolitik, mengkaji dampak yang ditimbulkan dalam proses partisipasi di dalam sistem politik, memonitor perkembangan agenda politik, dan memantau isu-isu yang muncul seiring dengan keterlibatan mereka di dalam sistem politik.

Penggambaran partisipasi politik perempuan pada lembaga sosial politik di Lembah Palu dalam kaitannya dengan peranan klen-klen yang ada, dapat ditelusuri berdasarkan bentuk dan lahirnya organisasi kemasyarakatan perempuan, konsep yang menyertai program pemberdayaan perempuan, nilai-nilai kultural yang melatar belakangi budaya masyarakat ataupun ideologi politik

http://www.komunitasdemokrasi.or.id/article/Memper kuat.pdf. diakses pada tanggal 09/2002 yang mewarnai proses politik yang terjadi di Lembah Palu.

Terbentuknya partai-partai politik sejak masa orde lama hingga masa orde baru, juga menandai secara nyata telah terjadi partisipasi perempuan dalam ruang-ruang publik. Pada beberapa partai politik di Sulawesi Tengah, representase partisipasi politik perempuan menunjukkan adanya peningkatan jumlah secara signifikan. Kebijakan pemberdayaan perempuan berakselerasi dengan peningkatan partisipasi politik perempuan dan semakin mendapatkan momentum ketika perempuan terlibat dalam kegiatan-kegiatan politik formal baik sejak pertama kali Pemilu digelar hingga menjelang Pemilu langsung tahun 2004. Kehadiran dan keterlibatan perempuan dalam proses politik ditegaskan secara nyata melalui berbagai kebijakan negara yang diejawantahkan dalam bentuk Undang-undang dan Peraturan Pemerintah.

Kepemimpinan perempuan pada masyarakat Kaili di Lembah Palu Sulawesi Tengah sesungguhnya merupakan fenomena yang telah ada sejak sistem pemerintahan Kerajaan masih berlaku. Secara historis, terdapat beberapa Kerajaan yang secara langsung dipimpin oleh perempuan. KerajaanKerajaan ini bahkan mengalami momentum kejayaaan selama beberapa periode dalam sejarah Tanah Kaili. Tercatat diantaranya Dato Maria di Kerajaan Palu, Gonenggati di Kerajaan Banawa Donggala, Nggilinayo, Sairalie (Madika kedua) dan Pue Bawa (Madika ke lima) dari Kerajaan Sigi di Sigi, Vumbulangi dari Kerajaan Bangga di Sigi serta beberapa raja perempuan lainnya yang terus menjalin hubungan dengan beberapa Kerajaan lainnya melalui proses kawin-mawin. $^{2}$

Siklus kepemimpinan dalam lembaga sosial politik dan lembaga pemerintahan saat

${ }^{2}$ Muhammad Djarudin Abdullah. 1975. Mengenal Tanah Kaili. Palu : Badan Pengembangan Pariwisata Sulawesi Tengah. 30 
ini di wilayah Lembah Palu ${ }^{3}$ Sulawesi Tengah yang meliputi Kabupaten Parigi Mautong, Kabupaten Donggala, Kabupaten Sigi dan Kota Palu yang merupakan Ibu Kota Propinsi Sulawesi Tengah sangat dominan dikuasai oleh beberapa anggota fam keluarga yang berasal dari beberapa klen dominan.

Pada masyarakat Kaili, penggolongan orang-orang sekerabat dapat diidentifikasi berdasarkan nama besar yang dikenali melalui identitas ayah yang dipergunakan seseorang, dengan ini seseorang akan diketahui siapa nenek moyangnya. Pembentukan klen dengan menggunakan fam (marga) dapat menunjukkan identitas seseorang dalam Masyarakat Kaili di lembah Palu. Ikatan genealogik pada satuan klen dalam masyarakat di Lembah Palu saat ini seringkali menjadi dasar pengelompokan anggota-anggota dalam kelembagaan politik ataupun kelembagaan masyarakat yang ada termasuk alasan-alasan pelibatan perempuan dalam partai politik dan birokrasi pemerintahan.

Berdasarkan ketentuan yang dipengaruhi oleh garis keturunan ayah (patrilineal) pada masyarakat Kaili, klen seseorang dapat dikenali melalui identitas ayah (marga) yang dipergunakan pada namanya. Demikian pula untuk menelusuri seorang anak berasal dari keuturnan siapa, maka harus diketahui siapa ayahnya karena dengan mengenal ayahnya akan diketahui siapa nenek moyangnya. Terbentuknya klen-klen juga dapat ditelusuri melalui kerabat ayahnya secara turun temurun bahkan klen tersebut menggunakan fam (marga) dari ayah sebagai identitasnya ${ }^{4}$.

${ }^{3}$ Lembah Palu adalah satuan wilayah geografis yang merupakan wilayah persebaran etnik Kaili dengan beberapa sub etniknya. Pada wilayah ini terdapat beberapa marga (klen) yang menguasai kepemimpinan dalam kelembagaan Politik sekaligus saling memiiki hubungan kekerabatan yang terjalin melalui ikatan perkawinan.

4 Di wilayah Lembah Palu nama-nama fam (marga) seperti Djanggola, Parampasi, Pettalolo, Lembah, Lamakampali, Ponulele, Lamarauna, Sunusi, Pakamundi, Latjambo, Lapasere dll merupakan
Partisipasi politik perempuan secara eksplisit terlihat nyata dalam pertarungan di legislatif. Perempuan yang dinominasikan menjadi calon legislatif cenderung akan diperhitungkan ketika berasal dari fam tertentu yang merupakan anggota klen dominan. Di Golkar misalnya calon-calon legislatif dapat diidentifikasi berdasarkan nama fam yang digunakan yang memiliki kedekatan genealogik dengan pemimpin partai tersebut. Demikian pula halnya dengan partai-partai lainnya, faktor genealogik karena menggunakan nama fam dalam klen dominan yang di anggap memiliki nilai jual ketimbang faktor lainnya. Sehingga secara relatif pada setiap parpol akan mudah ditelusuri hubungan kekerabatan antara tiap individu yang terlibat di dalamnya.

Sementara itu partisipasi politik perempuan untuk mendukung calon-calon legislatif perempuan tidak bersifat total. Dukungan politik perempuan akan diarahkan untuk memenangkan calon-calon tertentu yang memiliki hubungan kekeluargaan dan pilihan politik cenderung dijatuhkan pada calon-calon legislatif laki-laki. Demikian pula ketika menjelang pilkada atau pilgub, partisipasi politik perempuan sebagai kontestan sangatlah minim. Kehadiran perempuan untuk bertarung dan menjadi calon kontestan ada, namun faktor genealogik sangat menentukan partisipasinya. Status sebagai isteri, adik, kakak, anak, dan kemenakan seringkali menjadi indikator pertisipasi politik perempuan untuk menjadi calon kontestan dalam pilkada atau pilgub. Hingga saat ini ketika menjelang pilkada atau pilgub partisipasi politik perempuan untuk mendukung para kontestan juga ditentukan karena hubungan genealogik. Programprogram yang disampaikan para kontestan tidak sepenuhnya menjadi daya jual yang tinggi

penyebutan identitas keluarga yang didasarkan pada garis keturunan yang bersifat patrilineal dan biasanya nama perkumpulan kekerabatan yang dibuat oleh kesatuan kekerabatan tertentu akan menggunakan nama sesuai dengan identitas marga (nenek moyang laki-laki). 
untuk penentuan pilihan bagi perempuan meskipun program tersebut mengusung tema keberpihakan pada kepentingan perempuan.

Integrasi perempuan dalam lembaga sosial politik ataupun lembaga pemerintah di Lembah Palu terjadi karena adanya kekuatan yang membentuk ruang dalam proses partisipasi politik perempuan. Peranan klen merupakan faktor signifikan yang mempengaruhi pilihan perempuan untuk berpartisipasi dalam realitas politik tersebut. Apabila beberapa anggota klen yang berada dalam lembaga sosial politik ataupun lembaga pemerintah ingin mempertahankan keberlanjutan pengaruhnya agar lebih solid dalam memperkuat posisi dan kedudukan mereka maka tokoh utama klen atau elit-elit berpengaruh dalam klen dominan akan merekrut partisipan baru dari lingkungan sekerabat meskipun sumberdaya dari kalangan mereka masih terbatas. Fenomena ini senantiasa dijaga dan dipertahankan. Proses ini juga secara relatif berpengaruh terhadap partisipasi perempuan dalam proses politik karena keberadaan perempuan dalam proses politik senantiasa akan dikendalikan tokoh utama klen secara langsung ataupun tidak langsung. Pengendalian langsung diperankan oleh pimpinan atau ketua yang merupakan pemimpin puncak dari organisasi yang digelutinya. Pengendalian secara tidak langsung dimanifestasikan oleh kekuatan kharisma dan kekayaan serta luasnya jaringan keluarga atau kerabat.

\section{Politik Klen Pada Satuan Kekerabatan Masyarakat Kaili}

Secara garis besar klen adalah satuan kekerabatan yang diperhitungkan secara genealogi berdasarkan garis keturunan dari pihak ayah atau pihak ibu. Interaksi keanggotaan klen kadangkala berlangsung sangat dekat dan saling mendukung dalam tingkat solidaritas sanak saudara atau keluarga, namun dapat juga tidak saling mengenal karena keterbatasan jarak wilayah tempat tinggal.

Wouden mendefenisikan politik klen sebagai proses pelibatan anggota klen dalam kegiatan ataupun aktivitas politik atau upaya menempatkan anggota keluarga yang berasal dari satuan kekerabatan yang sama dalam struktur politik. Fenomena ini seringkali disebut juga sebagai politik dinasti atau politik kekerabatan dalam proses politik. ${ }^{5}$

Dasar kesatuan klen dapat menjadi dasar hubungan interaksi antara sesama anggota klen karena adanya kepentingan dan cita-cita yang sama dalam proses politik ${ }^{6}$. Dinamika politik pada era reformasi telah memunculkan pelaku dan lembaga-lembaga politik yang mulai memainkan peran di dalam proses politik. Pelaku yang terorganisir dan memiliki simbol kultural kuat biasanya hadir untuk mengisi panggung-panggung politik. Kemunculan pelaku politik tidak terlepas dari adanya jaringan kekerabatan atau klen dalam satuan geneologis yang sama atau berdasarkan garis unilinear.

Kushkrido Ambardi ${ }^{7}$ menyebut politik klen atau politik kekerabatan sebagai Politik Kartel yang membelit kelembagaan politik di Indonesia pada dekade ke dua pasca reformasi. Fenomena menguatnya politik kekerabatan dengan kecenderungan berada dalam politik lokal di Indonesia adalah hasil dari kombinasi tekanan politik sentripugal (terpusat) pada masa orde baru dan tekanan politik sentripetal (desentralisasi) pasca orde baru. Pada awal pelembagaan desentralisasi, pola ini belum terlihat akan tetapi memasuki dekade ke dua pasca reformasi kecenderungan pada semakin oligharkisnya kekuatan lembaga politik semakin

5 Van F.A.E. Wouden. 1985. Klen Mitos dan Kekuasaan (Terjemahan). Jakarta : PT. Temprint. 87

http://www.jpnn.com/read/2011/03/11/86405/Politi k-Kekerabatan-Membajak-Demokrasi diakses pada tanggal 12/9/2011

http://ellyasa.blogspot.com/2008/08/aroma-politikkekerabatan.html- diakses pada tanggal 15/9/2011 
bergerak ke arah yang lebih pragmatis. Politik kekerabatan memberi peluang menguatnya nepotisme, patron-klien, patrimonalisme, dan sistem rekrutmen yang tidak transparan dengan berbagai turunannya.

Pengamat Politik LIPI Siti Zuhro menyatakan bahwa demokrasi secara esensial seharusnya berkorelasi positif terhadap terciptanya pluralisme aktor. Dalam politik kekerabatan, yang terjadi justru sebaliknya, aktor yang muncul dalam proses demokrasi ini berputar di sekitar itu-itu saja tidak memunculkan variasi aktor. Dengan demikian trah, kekuasaan dan kelanggengan dinasti politik senantiasa terjaga dan terus menerus diakui dalam proses politik. ${ }^{8}$

Sistem kekerabatan merupakan mekanisme yang dijumpai secara universal dalam masyarakat. Bentuk sistem kekerabatan sangat berbeda antara satu masyarakat dengan masyarakat lainnya. Pada setiap kelompok masyarakat, sistem kekerabatan berfungsi untuk mengatur tingkah laku, susunan kelompok, dan hubungan sosial. ${ }^{9}$ Dalam sistem kekerabatan termuat uraian unsur-unsur yang mendasari kehidupan masyarakat seperti prinsip keturunan, aturan perkawinan, tipe orientasi, pengorganisasian masyarakat, dan berbagai hal yang menyangkut konsep kehidupan masyarakat baik yang bersifat sederhana ataupun yang bersifat kompleks.

Koentjaraningrat menguraikan unsurunsur sistem kekerabatan yang terdiri dari : (1) sistem norma yang mengatur tata kelakuan anggota kelompok; (2) rasa kepribadian kelompok yang disadari oleh semua anggotanya; (3) aktivitas berkumpul dari anggota kelompok secara berulang-ulang; (4) sistem hak dan kewajiban yang mengatur interaksi antar anggota; (5) adanya pimpinan atau pengurus yang mengorganisasi aktivitas

\footnotetext{
${ }^{8}$ Siti Zuhro R. 2009. Demokrasi Lokal: Peran Aktor Dalam Demokratisasi. Yogjakarta:Ombak, 27

${ }^{9}$ Koentjaraningrat. 1981. Beberapa pokok. Antropologi Sosial. Jakarta : Dian Rakyat., 142
}

kelompok; dan (6) sistem hak dan kewajiban bagi setiap individu terhadap jumlah produksi, harta konsumsi, ataupun harta warisan. ${ }^{10}$

Suatu masyarakat pasti memiliki kelompok kekerabatan tertentu dengan ciri khas yang membedakannya dengan kelompok kerabat lainnya pada masyarakat yang berbeda. Kekerabatan mempunyai peranan dalam proses terwujudnya kelompok dan satuan sosial lainnya. ${ }^{11}$ Orang-orang sekerabat cenderung untuk membedakan dirinya dari orang-orang yang tidak sekerabat dan kecenderungan ini menjadi landasan bagi terbentuknya kelompok kekerabatan. Satu kelompok kekerabatan terkecil dimulai dari terbentuknya satu keluarga inti atau keluarga batih. Keluarga batih kemudian selanjutnya berkembang hingga mencapai bentuk-bentuk kelompok kekerabatan yang lebih luas dengan fungsi-fungsi sosial yang dimilikinya semakin besar.

Beberapa bentuk kelompok kekerabatan yang dikenal secara umum dalam kehidupan masyarakat. Kelompok kekerabatan tersebut diantaranya, seperti Kindred, Keluarga Luas, Keluarga Ambilineal Kecil, Keluarga Ambilineal Besar, Klen Kecil dan Klen Besar. ${ }^{12}$ Fungsi klen besar secara umum menurut Koentjaraningrat terdiri dari empat hal yaitu: (1) mengatur perkawinan; (2) menyelenggarakan kehidupan keagamaan dari seluruh kelompok kesatuan; (3) sebagai dasar dari hubungan-hubungan antar kelas-kelas berlapis (stratifikasi sosial) dalam masyarakat; (4) dan menjadi dasar dari organisasi politik. ${ }^{13}$ Fungsi keempat klen besar sebagai dasar bagi organisasi politik akan tampak dalam penguasaaan wilayah pemerintahan dimana satu klen besar menguasai beberapa kelompok kerabat dalam memimpin berjalannya satu pemerintahan. Meskipun kondisi ini sudah 
relatif jarang dijumpai tetapi beberapa komunitas masyarakat lokal dalam menjalankan proses pemerintahan dan kebijakan politik relatif masih bersandar pada figur seorang tokoh yang ditunjuk karena silsilah keturunan nenek moyang dalam klen tertentu. Kondisi ini juga mempengaruhi munculnya tokoh-tokoh politik yang seringkali dinilai berdasarkan garis keturunannnya khususnya pada wilayahwilayah yang masih bersandar pada ikatan kekerabatan yang kuat.

Pada masyarakat Kaili, klen terbentuk dari hubungan kekerabatan yang dibangun berdasarkan prinsip Bilineal. Pada prinsip bilineal terdapat beberapa ketentuan atau aturan tertentu diperhitungkan berdasarkan garis keturunan ibu (matrilineal) dan untuk beberapa ketentuan atau aturan tertentu diperhitungkan berdasarkan garis keturunan ayah (patrilineal). ${ }^{14}$ Ketentuan yang diperhitungkan berdasarkan garis keturuan ibu (matrilineal) dapat ditelusuri pada sistem pewarisan dan adat menetap sesudah nikah. Adapun ketentuan yang diperhitungkan berdasarkan garis keturunan ayah (patrilineal) dapat dikenali dengan penggunaan fam atau marga ayahnya. ${ }^{15}$

Ketentuan tertentu yang dipengaruhi oleh garis keturunan matrilineal salah satunya dapat dikenali melalui pranata Bulonggo yang menguraikan tentang peran yang dimiliki anak perempuan dalam mengurus, mengelola dan dan menjaga harta warisan keluarga. Dalam pranata ini diperhitungkan sejumlah hak dan kewajiban tertentu yang dimiliki oleh anak perempuan. Perempuan diposisikan secara khusus sebagai subyek yang memiliki kontrol dalam mengatur sumber-sumber ekonomi keluarga terutama untuk memelihara dan mengelola pemanfaatan harta ataupun warisan yang dimiliki oleh keluarga ketika warisan belum dibagi-bagi. Pranata ini membentuk karakter perempuan untuk senantiasa memiliki

14 Ibid., 127

15 Mashudin Masyhuda. 1982. Mengenal Sulawesi Tengah. Palu : Yayasan Kebudayaan Sulawesi Tengah. 23 rasa tanggung jawab dan sikap kepemimpinan sosial karena dalam pranata ini diatur mengenai hak dan kewajiban perempuan dalam masyarakat. Ini sangat terkait dengan mitos to manuru yang menjelaskan tentang asal muasal pemimpin pada suku kaili.

Mitos to manuru adalah kisah tentang penjelmaan manusia dari kayangan yang diyakini oleh masyarakat kaili sebagai cikal bakal pemimpin atau penguasa yang membawa pengaruh dalam kehidupan masyarakat. Mitos ini menceritakan tentang sosok tomalanggai seorang laki-laki sakti penguasa kelompok yang kemudian mengawini seorang wanita jelmaan dewa yang keluar dari dalam bambu kuning keemasan (Bolo Vatu Bulava). Tomalangganlah yang kemudian dianggap merupakan cikal bakal pemimpin pada masyarakat Kaili. Dari perkawinan keduanya lahir para pemimpin yang secara turun-temurun menjadi penguasa pada beberapa kerajaan di suku Kaili.

Masyarakat Kaili meyakini bahwa kehadiran to manuru sebagai isteri memberi pengaruh besar bagi perubahan sosok Tomalanggai dimana kesaktian dan pengaruhnya semakin bertambah disertai sikapnya yang semakin arif dan bijaksana. Faktor inilah yang membentuk karakter anak yang menjadi pengganti dan penerus Tomalanggai dan diangkat sebagai raja secara turun temurun dengan tetap mewarisi ilmu dan sikap yang dimiliki oleh ayahnya. Peran to manuru sebagai ibu juga memberi andil besar dalam membentuk karakter anaknya dengan memberikan nasihat-nasihat untuk menjalankan pemerintahan yang bijaksana.

Adapun karakteristik prinsip bilineal yang dipengaruhi oleh garis keturuan ayah (patrilineal) adalah penggunaan nama fam atau marga pada masyarakat kaili. Penggunaan nama fam atau marga merupakan dasar untuk menelususri klen seseorang. Lingkup satuan kekerabatan dalam klen mengalami perluasan karena hubungan kawin- mawin antar sepupu 
(paralel causin) yang Endogamy ataupun melalui perkawinan Exogamy.

Pelibatan anggota klen dalam proses politik merupakan bentuk pewarisan kepentingan ekonomi politik dalam rangka memelihara posisi strategis dan memapankan status quo beberapa orang dalam lembaga sosial politik yang berasal dari klen tertentu. Keberadaan seorang pemimpin dalam lembaga sosial politik biasanya diperhitungkan berdasarkan latar belakang kekuasaan adat yang pernah dipegang oleh nenek moyangnya dalam pemerintahan kerajaan. Pemimpin kelembagaan masyarakat dan kelembagaan politik cenderung akan dipercayakan pada lakilaki yang secara genealogi merupakan keturunan dari Tomalanggai. Tomalanggai diyakini memiliki perilaku, sifat dan karakter yang tegas dan berani sehingga secara ideal senantiasa harus tercermin dari seorang pemimpin yang diyakini ada pada diri seorang laki-laki. Selain itu kelayakan seorang pemimpin bagi masyarakat Kaili biasanya akan diperhitungkan berdasarkan silsilah keturunannya yang merupakan keturunan para pemimpin pada Libu Nu madika (bangsawan), yang terdiri Magau dari Madika Malolo (wakil Magau), Madika Matua (Perdana Menteri), Punggava (Menteri dalam Negeri),Galara (kehakiman), Tadulako (panglima perang), Pabicara (Menteri Penerangan), dan Sabandara (Menteri Perhubungan). Selain itu silsilah keturunan dalam kekuasaan adat pada masyarakat Kaili juga ditarik dari keturunan To Tua Nungata yang menduduki jabatan pada Libu Nto Dea. Pada zaman pemerintahan kerajaan Libu Nto Dea merupakan perwakilan tiap-tiap Soki (kampung atau ngata). Keberdaan Libu Nto Dea merupakan lembaga permusyawaratan yang bertugas menyusun dan mengawasi jalannya pemerintahan.
Bourdieu (2008) ${ }^{16}$ menyatakan bahwa pertalian darah (ikatan genealogi) dalam satuan kekerabatan dianggap lebih dapat dipercaya dan tidak mungkin berkhianat seperti lazim dilakukan politikus pemburu kekuasaan. Para elite politik atau tokoh sentral yang berpengaruh secara masif mengusung anggota keluarga menjadi caleg atau calon kepala daerah karena political privileges keluarga, yang hanya memproduksi politisi karbitan yang tidak memiliki kualitas dan kualifikasi yang memadai untuk memimpin atau menjadi anggota legislatif, dan bukan political credentials kreasi mereka sendiri, yang melahirkan politisi sejati dan otentik.

Keberadaan perempuan dalam lembaga sosial politik yang berasal dari klen dominan diperhadapkan pada situasi untuk selalu mendukung sepenuhnya kebijakan pemimpin lembaga sosial politik yang berasal dari klen yang sama yang nota bene adalah tokoh-tokoh sentral yang berpengaruh. Dalam situasi ini, meskipun terdapat beberapa hak yang dimiliki seorang perempuan berdasarkan prinsip bilineal namun perempuan dianggap tidak mewarisi karakter Tomalanggai sehingga pandangan tentang romantisasi kedirian perempuan lebih cocok dengan peran komplementer tetap ada. Posisi ini mengakibatkan partisipasi politik perempuan tidak dapat bersentuhan langsung dengan ruang-ruang yang dapat memajukan potensi kedirian perempuan dimana kehadiran perempuan lebih bersifat komplementer. Kondisi ini berdampak negatif terhadap perempuan yang berusaha melaksanakan peran mereka secara optimal.

Secara simultan, Klen dalam proses politik memiliki sifat menampilkan ciri primordialisme. Anggota klen yang merupakan kelompok kekerabatan senantiasa menjalin hubungan sesama anggotanya di lembaga sosial politik pada masyarakat Kaili. Klen

http://ellyasa.blogspot.com/2008/08/ op. cit.- di akses pada tanggal 12/9/2011, 
memiliki beberapa faktor yang membentuk dominasi dalam proses politik dalam rangka mempertahankan kelanjutan regenerasi dan mengendalikan kepentingan anggota klen yang terlibat dalam lembaga sosial politik yang ada. Faktor-faktor yang membentuk peranan klen tersebut adalah melanggengkan kedudukan (kadudua), mempertahankan kekayaan (kasugia), karakter kepemimpinan (Tomalanggar), memperluas hubungan solidaritas (sintuvu Posarara) dan melemahnya pemahaman pranata Bulonggo.

\section{Klen-klen Dominan Pada Masyarakat Kaili}

Masyarakat Kaili diikat oleh kelompok kekerabatan yang mereka sebut sebagai Santina sebagai satuan kekerabatan terus berkembang hingga membentuk klen. Saat ini di tiap wilayah yang huni oleh masyarakat Kaili di Lembah Palu ditemukan beberapa kelompok masyarakat yang merupakan klen yang mana warganya telah menyebar ke beberapa wilayah lain. Klen-klen ini pada awalnya dapat saja berasal dari satu kampung (teritorial) yang sama yang berbentuk ngata (kampung). Bahkan penggunaan kata Lembah pada beberapa klen yang besar saat ini secara teritorial terkait dengan wilayah hunian awal klen tersebut berasal. Klen-klen tersebut secara terus menerus mengalami perluasan dengan terjadinya perkawinan antar madika dan magau (nosibolai). Pada tiap ngata terbentuk ikatan kekerabatan yang semakin erat antara tiap-tiap klen sehingga jaringan hubungan berdasarkan genealogik semakin kuat.

Perkawinan antar bangsawan menjelaskan bahwa garis genealogik beberapa klen (marga) seperti Parampasi, Djanggola, Djaelangkara, Lamakarate, Karandjalemba, Randalemba, Lamakampali, Lamarauna, Malonda, Pettalolo, Lembah, Yotolembah yang tetap terjaga eksistensinya hingga saat ini.Beberapa klen lainnya seperti Ponulele, Datu Palinge, Lapasere, Pakamundi, Lamangkona, Intjeote, Latjambo, Tombolotutu, Abdullah, Sunusi juga dominan keberadaannya saat ini. Klen-klen ini sesungguhnya memiliki asal leluhur yang sama. Mereka terbentuk dari perkawinan yang terjadi diantara golongan Madika sebelumnya. Ini terlihat dari faktor genealogik diantara mereka yang hinggaa kini dikategorikan sebagai golongan Madika.

Hubungan kekerabatan yang terjalin melalui ikatan perkawinan (adat Nosibolar) antar keluarga raja dan bangsawan tetap terpelihara dan berlangsung hingga kini. Ikatan perkawinan telah menyatukan madika di lembah Palu bahkan membentuk klen-klen besar dengan status sosial tersendiri. Dalam perkawinan, klen-klen ini pada umumnya memelihara adat perkawinan exogamy. Seorang laki-laki dapat kawin dengan perempuan dari klennya sendiri minimal dalam derajat ke satu (sarasanggani) atau memilih perempuan di luar klen baik yang sederajat ataupun yang tidak sederajat. Perkawinan exogamy dimaksudkan sebagai upaya memelihara dan menjaga kualitas dan kemurnian darah turunan dari keluarga bangsawan dalam klen yang sama.

Pada masyarakat kaili di lembah Palu saat ini klen-klen besar terus meluas dan menguasai posisi-posisi strategik dalam proses politik dan dalam kegiatan kemasyarakatan. Ponulele, Parampasi, Pettalolo, Lembah, Yoto Lembah dan Djanggola adalah klen-klen besar saat ini yang menguasai posisi strategik dalam proses politik. Keberadaan anggota klen-klen dapat diidentifikasi dari fam yang dimiliki. Mereka biasanya berasal dari kesatuaan klen yang terkait hubungan kerabat seperti ana (anak), pinoana (kemenakan), sarasanggani (sepupu dalam derajat ke satu), sarara ruanggani (sepupu dalam derajat kedua), sarara talunggani (sepupu dalam derajat ketiga), mania (mantu), era (ipar), mangge (Paman), pinotina (Bibi), bahkan makumpu (cucu). Nama besar marga (klen) yang disandang seseorang seringkali menjadi dasar pertimbangan untuk dapat menduduki jabatan atau posisi tertentu dimasyarakat. 
Seseorang yang memiliki fam besar dan terkenal di masyarakat masih cukup dihormati karena faktor genealogik yang disandangnya. Posisinya di masyarakat akan semakin dihargai dan mendapat ruang jika berada dalam lingkup kerabat seorang pejabat atau tokoh yang berasal dari klen besar dan terkenal. Kenyataan ini juga menandai proses partisipasi politik perempuan dan pada kegiatan-kegiatan kemasyarakatan lainnya.

Peralihan masa pemerintahan kerajaan menjadi pemerintahan moderen yang dibarengi dengan berakhirnya penjajahan di Tanah Kaili menciptakan terbukanya situasi dan ruang-ruang sosial baru bagi terbentuknya politik kekerabatan. Besarnya andil para tokoh masyarakat yang nota bene berasal dari klenklen dominan dalam pembentukan lembagalembaga politik dan dalam memperjuangkan wilayah pemerintahan otonom Sulawesi Tengah menyebabkan mereka mendapat peran dan kedudukan dalam proses pelaksanaan pemerintahan transisi ketika itu, selain itu faktor genealogik bahwa mereka adalah keturunan Magau dan Madika yang diyakini memiliki pengaruh dan keutamaan dalam masyarakat.

Dengan adanya mereka sebagai personalisasi figur sentral memungkinkan pelibatan anggota klen-klen dominan berlangsung secara konstan dan berkesinambungan yang pada akhirnya memunculkan figur-figur baru sebagai pemimpin dan tokoh-tokoh yang di segani saat ini. Saat ini dengan keberadaan para tokoh dan figur-figur sentral yang menjadi pemimpin pada lembaga pemerintahan dan kelembagaan politik, memungkinkan terjadinya partisipasi politik yang melibatkan anggota klen-klen dominan yang ada termasuk anggota klen perempuan.

\section{Distribusi Perempuan Klen Dominan dalam Partisipasi Politik.}

Pada lembaga pemerintah proses keterlibatan perempuan anggota klen dominan terjadi ketika salah seorang anggota klen dominan menduduki posisi puncak sebagai kepala daerah. Jika pemimpin wilayah seperti Gubernur, Bupati dan Walikota yang menjabat berasal dari klen dominan, maka dapat dipastikan ketika terjadi proses rotasi dan pengisian jabatan maka anggota klen dominan yang menjadi pejabat wilayah tersebut akan menempatkan anggota klennya untuk mengisi beberapa jabatan yang ada. Perempuan anggota klen terdekat yang berasal dari anggota keluarga batih yang sama dan kerabat terdekat bahkan kerabat diluar lingkaran klennya tetapi memiliki hubungan dekat juga mendapatkan jabatan yang disesuaikan dengan kelayakan pangkat yang dimiliki disamping dasar pertimbangan adanya hubungan genealogik.

Secara umum, perempuan pada klen dominan ini mengawali keterlibatannya dalam aktivitas lembaga kemasyarakatan dan partai politik berdasarkan rekruitmen yang dilakukan ketika suksesi kepemimpinan internal lembaga terjadi. Pada proses ini lazim terjadi pergantian pengurus lembaga kemasyarakatan dan partai politik dimana yang berhak menentukan untuk mengisi jabatan pengurus adalah pemimpin puncak lembaga yang terpilih. Dalam proses ini dapat dipastikan anggota klen yang berada dalam kesatuan kekerabatan pemimpin puncak akan terekrut terutama jika anggota klen pernah berada pada lingkaran kekuasaan sebelumnya yang dimiliki pemimpin puncak. Keberadaan anggota klen perempuan juga dengan mudah direkrut sebagai bentuk mediasi terhadap sumber daya perempuan yang tersedia dalam klen dominan tersebut.

Perempuan anggota klen dominan yang memiliki hubungan kekerabatan yang erat dengan pemimpin puncak akan ditempatkan pada posisi yang dianggap sangat strategik, misalnya posisi pengelola keuangan dan logistik organisasi. Hal dilakukan karena figur tersebut dianggap mampu menjalankan kebijakan 
organisasi khususnya kepentingan pemimpin puncak. Jumlah mereka biasanya tidak banyak dan secara genealogik masih merupakan kerabat dekat seperti adik, ponakan bahkan isteri. Sementara untuk jabatan strategik seperti wakil sekretaris dan bidang tertentu biasanya akan diduduki oleh beberapa fungsionaris organisasi perempuan yang memiliki hubungan kekerabatan yang relatif dekat misalnya sepupu dalam derajat kedua atau sepupu derajat ketiga. Adapun perempuan fungsionaris organisasi lainnya yang berasal klen dominan lain tetapi masih terikat hubungan perkawinan atau bahkan dari klen yang tidak dominan biasanya akan di tempatkan pada jabataan yang tidak strategik.

Persebaran perempuan anggota klen dominan terdapat pada beberapa partai politik. Perempuan anggota klen dominan memilih untuk terlibat pada partai politik besar yang memiliki hirarki kepengurusan yang berada pada tingkatan Dewan Pengurus Daerah di tingkat Propinsi sampai pada kepengurusan ranting di tingkat Desa atau Kelurahan. Pada Partai Politik yang dimasuki telah terbentuk organisasi sayap dimana perempuan anggota klen dominan mudah terlibat karena adanya figur sentral klen dominan yang memimpin partai politik tersebut.

Pengaruh kekerabatan di dalam lembaga politik seperti partai politik dapat menjaga eksistensi karir politik perempuan anggota klen dominan menjadi semakin kuat, karena jika mereka telah berada di partai politik maka kemungkinan untuk masuk di lembaga legislatif semakin terbuka. Posisinya mereka untuk berada pada dua lembaga politik tersebut sangat berkaitan dengan keberadaan mereka sebagai anggota klen dominan. Dengan status mereka sebagai anggota klen dominan maka ruang partisipasi politik semakin terbuka karena adanya dorongan dari satuan kekerabatan yang melingkarinya sehingga mereka sulit untuk digeser dan digantikan.
Pada organisasi perkumpulan berbasis kegiatan usaha partisipasi perempuan anggota klen dominan cenderung menampilkan realitas yang berbeda. Perempuan anggota klen dominan cenderung lebih memilih terlibat pada organisasi perkumpulan yang khusus mengelola kegiatan keperempuanan ketimbang organisasi perkumpulan profesi yang mengelola jasa di bidang umum. Hal ini disebabkan sumber daya perempuan dari klen dominan relatif terbatas untuk mendukung kegiatan yang dilakukan oleh organisasi perkumpulan yang berbasif profesi karena memerlukan keahlian. Organisasi ini biasanya akan melibatkan perempuan yang memiliki profesionalisme berdasarkan bidang kegiatan yang dilakukan. Organisasi perkumpulan tersebut adalah yang bergerak pada kegiatan jasa konstruksi, atau lembaga jasa umum lainnya.

Partisipasi perempuan anggota klen dominan dalam organisasi perkumpulan yang berbasis kegiatan usaha yang khusus mengelola kegiatan keperempuanan diyakini akan dapat mempermudah pengelolaan kegiatan organisasi yang dilaksanakan. Berdasarkan posisi mereka yang menduduki jabatan strategik dalam organisasi, diyakini dapat berperan membangun jaringan dan dukungan baik kebijakan ataupun dana yang dibutuhkan oleh organisasi. Peran yang dijalankan oleh perempuan anggota klen dominan ini didasari pada adanya kedekatan hubungan kekerabatan dengan pemimpin puncak lembaga pemerintah atau pemimpin partai politik tertentu sebagai penentu kebijakan yang dibutuhkan.

Proses distribusi peran di masyarkat Kaili menggambarkan bahwa perempuan klen dominan secara relatif terlibat pada setiap lembaga sosial politik baik institusi pemerintah, lembaga politik, ormas ataupun organisasi perkumpulan berbasis kegiatan usaha. Meskipun jumlah mereka yang menduduki posisi sangat startegis hanya sedikit jumlahnya atau sekitar sekitar $1-4$ orang tetapi mereka 
adalah kerabat dekat yang merupakan keturunan langsung dari pemimpin puncak lembaga yang nota bene adalah juga berasal dari anggota klen yang sama.

Keterlibatan perempuan klen dominan yang menduduki posisi strategik pada institusi pemerintah juga relatif signifikan. Demikian juga pada lembaga politik, ormas ataupun organisasi perkumpulan, hubungan mereka dengan pemimpin puncak lembaga berbentuk hubungan kekeluargaan seperti ponakan dan sepupu dalam derajat tertentu. Partisipasi politik perempuan yang tidak terikat dalam klen dominan menunjukaan realitas yang berbeda. Pilihan untuk berperan dalam lembaga pemerintahan, lembaga politik dan lembaga kemasyarakatan cenderung lebih bebas. Mereka tidak terikat pada kepentingan pemimpin puncak lembaga atau organisasi dimana mereka terlibat. Keterlibatan mereka dalam lembaga hampir tidak memiliki peran strategik karena mereka hanya sebatas menjalankan kegiatan rutinitas lembaga sesuai dengan mekanisme yang disediakan lembaga. Orientasi mereka cenderung untuk menambah pengalaman berorganisasi dan meningkatkan kapasitas pribadi.

\section{Implikasi Politik Klen Pada Partisipasi Politik Perempuan}

Fakta yang menunjukkan bahwa kualitas pribadi perempuan dapat diandalkan sebagai sesuatu yang determinan di dalam superioritas klen juga akan memberikan suatu gambaran bahwa mereka telah dilibatkan kedalam proses suksesi pada akses peran dan posisi strategik dalam pengambilan keputusan di tingkat lembaga politik ataupun organisasi. Realitas yang ada menunjukkan bahwa klenklen dominan menjadi sumber rekruitmen yang dapat diandalkan untuk memperoleh aktivis perempuan yang dapat ditempatkan pada posisi penting dan berpengaruh.

Perempuan dalam lingkaran klen dominan di Lembah Palu yang terlibat dalam lembaga politik ataupun organisasi masyarakat cenderung lebih memperlihatkan adanya kelemahan. Rekruitmen dalam organisasi sosial ataupun lembaga politik termasuk organisasi masyarakat (ormas) yang merupakan sayap partai politik (parpol) yang terkait dengan pelibatan perempuan dari klen dominan berjalan terlampau mudah dan sederhana. Dalam beberapa ormas bahwa para perempuan dari klen dominan relatif sedikit jumlahnya diantara mereka yang memiliki pendidikan setingkat sarjana apalagi magister.

Pada beberapa organisasi politik di Lembah Palu banyak aktifis perempuan dari klen dominan tidak melalui tahapan ideal untuk menjadikan dasar pengalaman berorganisasi hingga masuk ke posisi strategik dalam organisasi. Kalaupun mereka menjadi matang dalam organisasi oleh karena mereka telah mengalami sebuah proses pembelajaran setelah mereka menduduki posisi tertentu setelah sekian lama mengisi kesempatan untuk membenahi pengalaman mereka dalam berorganisasi termasuk mengikuti pelatihan manejemen dan kaderisasi. Kebiasaan ini menjadi alasan bagi pemimpin puncak atau elit politik yang berasal dari klen dominan lazim menempatkan orang kepercayaan yang dekat secara genealogik untuk mengamankan sumber vital organisasi yaitu sarana prasarana logistik dan keuangan. Penelitian di lapangan menunjukkan bahwa para aktifis perempuan dari klen dominan biasanya memiliki tugas ganda, sungguhpun posisi bendahara atau sekretaris telah ditempati namun dapat saja secara bersamaan mereka diberi akses yang luas untuk mengatur logistik dan keuangan atas perintah pimpinan. Sementara itu, mereka umumnya tidak diberi bekal yang memadai untuk mengelola administrasi secara baik, sehingga tugas yang diberikan tidak menjadikan dirinya memiliki kompotensi dan pengalaman profesional dalam pengelolaan keuangan dan barang. 
Keterlibatan perempuan dari klen dominan dalam organisasi cenderung dihasilkan melalui proses rekruitmen yang tidak didasarkan pada profesionalitas. Beberapa perempuan tersebut tanpa pengalaman organisasi yang memadai justru memperoleh posisi yang strategik dan akses yang luas terhadap pengambilan keputusan, meskipun secara relatif harus diakui bahwa terdapat beberapa perempuan anggota klen dominan yang telah memiliki kualitas yang baik, dilihat dari aspek pendidikan ataupun pengalaman organisasi. Sementara partisipasi politik perempuan yang tidak berasal dari anggota klen dominan yang secara esensi memiliki kualitas sumber daya yang memadai dan memiliki syarat-syarat formal yang layak untuk menduduki jabatan di pemerintahan, tetapi karena pertimbangan utama dalam proses rekruitmen didasarkan pada latar belakang genealogik yang berasal dari lingkaran dekat klen dominan dan jauh dari dengan kedekatan pemimpin puncak lembaga menjadikan mereka sulit untuk diakomodir dalam lembaga politik atau pemerintahan.

Klen dominan memberi kontribusi sangat penting dalam proses rekruitmen tersebut, tetapi sekaligus mengandung kelemahan pada dirinya sendiri terhadap proses rekruitmen yang dihasilkan karena pelibatan aktifis perempuan dalam organisasi kemasyarakatan atau lembaga politik tidak ditentukan berdasarkan kapasitas dan kompetensi pengetahun yang memadai. Jikapun diseleksi secara terbuka dan obyektif di hadapan khalayak umum seorang aktifis perempuan klen dominan akan menghadapi pesaing dari figur-figur yang tidak berasal klen dominan tetapi memiliki kapasitas lebih baik dari segi latar belakang pendidikan ataupun pengalaman organisasi.

Perempuan dari klen dominan cenderung menunjukkan gairah kurang optimistik untuk menyatakan bahwa mereka benar-benar memiliki minat kuat mengelola organisasi secara profesional. Melihat posisi mereka yang sangat strategik sebagai fungsionaris organisasi, maka ruang untuk menjalankan roda organisasi sesungguhnya sangat terbuka, seharusnya organisasi itu dapat berjalan sesuai fungsinya, setidaknya sebagai pelayanan anggota dan penataan peran masingmasing pengurus berdasarkan struktur kewenangan yang telah ditetapkan. Organisasi biasanya hanya melaksanakan kegiatan seremonial yang berlangsung kadangkala. Status genealogik yang melatar belakangi seorang aktifis organisasi biasanya menjadi alasan untuk mendapat kehormatan menduduki jabatan lain di beberapa organisasi yang berbeda orientasinya. Fenomena ini juga ditunjang dengan kedangkalan dan ketidak pedulian mereka untuk mendalami visi dan missi organisasi, struktur kewenangan organisasi secara baik, akibatnya mereka seringkali melaksanakan lebih dari satu kewenangan dengan pemikiran bahwa mereka dipercayakan untuk bertanggung jawab terhadap semua hal dalam organisasi. Pada beberapa organisasi tertentu memahami program kegiatan selalu bermakna pada proyek pengadaan.

Perempuan anggota klen dominan dari klen dominan telah dikenal dan diterima secara baik oleh anggota organisasinya atau kelompok kepentingan di luar organisasi mereka terlibat. Latar belakang mereka sebagai anggota dari kesatuan klen dominan dan terkadang memiliki hubungan kekerabatan dengan pemimpin puncak sebuah organisasi atau elit politik tertentu dapat menjadi modal utama bagi terbangunnya komunikasi politik dengan berbagai pihak.Dalam posisi seperti itulah adakalanya mereka menjadi penyedia informasi utama dan terpercaya untuk menjelaskan kepada pihak luar tentang agendaagenda organisasi, sikap pimpinan terhadap perkembangan politik yang terjadi dan mengenai siapa orang penting yang sering berkomunikasi dengan pimpinan organisasi 
mereka. Memang seringkali kepercayaan ini diberikan kepada mereka oleh pimpinan sebagai bentuk dari adanya hubungan genealogik

Pola hubungan patrimonial menempatkan komunikasi antar anggota klen dominan berjalan sesuai dengan kendali figur pimpinan yang berada pada posisi puncak di lembaga politik dan pemerintahan yang harus ditaati, bersifat perintah, daan bahkan dapat menjadi keputusan, semua pola hubungan sosial terbangun bersifat kaku dan terkadang sepihak. Ketaatan yang berlebihan terhadap pimpinan selaku pemangku otoritas klen meski dalam konteks organisasi telah menjadikan para perempuan anggota klen dominan mempunyai prilaku yang cenderung eksklusif. Cenderung memperlihatkan tindakan protektif terhadap pimpinan untuk memberi kesan agar pimpinan membatasi untuk berkomunikasi pada orang-orang tertentu yang dianggap tidak perlu. Di lain pihak juga terbentuk kesan bahwa dirinyalah salah seorang yang mendapat amanah dari lingkungan klen untuk menjaga kredibilitas pimpinan. Sebenarnya prilaku ini diperlihatkan bermaksud menaikan gengsi pimpinan sebagai representasi klen dan pernyataan mereka berada dalam puncak kehormatan. Dalam konteks tersebut komunikasi politik yang ditampilkan oleh perempuan dari klen dominan ini menunjukkan mereka berada dalam posisi lemah secara organisasi, karena mereka tidak memiliki kreatifitas untuk mengolah informasi organisasi yang komprehensif kecuali sejauh batas-batas yang diberikan pimpinannya, karena hubungan mereka yang bersifat patrimonial.

Dalam konsep Sintuvu Posarara pada kehidupan masyarakat Kaili saat ini memberi pengaruh kuat terhadap pelibatan perempuan dalam kepemimpinan di masyarakat khusunya pada partisipasi politik perempuan. Konsep ini telah mendorong dan memberi ruang bagi perempuan untuk terlibat secara intens dalam kegiatan di kelembagaan politik dan organisasi kemasyarakatan. Beberapa perempuan yang berasal dari klen dominan mengambil peran untuk mengisi ruang-ruang partisipasi politik yang tersedia. Fenomena ini sebagai proses untuk melatih perempuan dalam mengembangkan kemampuannya sekaligus memperluas jaringan dan kepentingan klen dominan dimana aktivis perempuan tersebut terlibat.

Konsep Sintuvu Posarara dapat mendukung bagi tersalurnya kebutuhan dan kepentingan anggota masing-masing klen dominan yang ada. Meluasnya jaringan kekerabatan yang terbentuk berdasarkan Sintuvu Posarara dapat tetap berlangsung karena dipertahankan untuk melanggengkan dan memberi keuntungan bagi bertahannya mekanisme untuk mempertahankan dominasi politik. Konsep ini membawa akibat pada terciptanya situasi yang dibutuhkan untuk menata persepsi dan hubungan dalam kesatuan klen agar terajut ikatan kekeluaragaan sebagai dasar bangunan politik yang kuat, membangun solidaritas dan toleransi yang kuat diantara sesama anggota klen serta membangun kepentingan bersama dengan prinsip saling mendorong anggota klen pada posisi strategik di kelembagaan politik atau diorganisasi kemasyarakatan yang ada sehingga proses partisipasi politik semakin terbuka bagi anggota klen pada masyarakat Kaili.

Keberadaan anggota klen dominan dalam menempati posisi-posisi kunci dan jabatan strategik serta selalu mendapat keutamaan di institusi pemerintahan, lembaga politik, dan organisasi masyarakat merupakan sebuah realitas yang terbentuk dari proses pewarisan kekuasaan politik yang telah berlangsung lama. Proses tersebut terjadi karena adanya personalisasi figur-figur sentral yang berpengaruh yang juga merupakan anggota dari klen-klen dominan yang notabene adalah golongan Madika dan keturunan dari 
pemimpin informal yang pernah memegang kekuasaan adat.

Distribusi perempuan klen dominan yang mengisi institusi pemerintah, lembaga politik, ormas ataupun organisasi perkumpulan dengan kualitas keterlibatan yang dikaitkan dengan bentuk ikatan hubungan yang melingkarinya mengakibatkan peran perempuan menjadi tereduksi oleh kepentingan pemimpin puncak lembaga sekaligus dapat memporkokoh jangkauan kepentingan dan eksistensi klen dominan menjadi lebih mapan dalam penguasaan materi dan kekuasaan. Pemimpin puncak lembaga berusaha memperjuangkan dan melakukan langkah untuk memelihara geneologi politik di kalangan anggota keluarganya sendiri. Langkah ini dilakukan untuk kepentingan menjaga kekuasaan dan keberlangsungan karir politik. Dengan cara demikian, maka dengan sendirinya akses-akses ekonomi yang selama ini dibangun bisa diwariskan kepada penerusnya melalui keluarga atau bahkan kepada klen dominannya. Realitas menunjukkan bahwa peran dan partisipasi politik perempuan pada lembaga sosial politik dengan anggota dan kepengurusan yang terikat dalam hubungan kekerabatan apalagi yang ada dalam kesatuan klen dominan lebih terikat dan terpola pada ikatan kekerabatan yang terjalin. Terdapat ketidaksetaraan distribusi kekuasaan politik dimana posisi-posisi strategik banyak didistribusikan atas dasar hubungan kekeluargaan.

\section{Kesimpulan}

Proses politik menggambarkan bahwa dominasi klen merupakan fakta yang paling berpengaruh terhadap partisipasi politik perempuan pada masyarakat Kaili di lembah Palu. Dominasi klen menjadi suatu yang nyata oleh adanya proses perubahan sosial pada lembaga adat sebagai sistem kekuasaan pada masa lampau yang berfungsi memerintah, selanjutnya mengalami perubahan eksistensi sebagai lembaga yang bersifat kultural normatif yang berfungsi sebagai pembina perilaku, penata integrasi sosial dan identitas kelompok. Dalam realitas seperti itu kewibawaan lembaga adat masih tetap terjaga oleh karena menjadi faktor determinan menguatnya dominasi klen dalam struktur sosial dimana anggota klen dominan dapat menempati puncak-puncak status sosial dan peran-peran strategik dalam kelembagaan sosial politik.

Realitas dominasi klen terjadi karena proses transformasi kekuasaan adat. Sebuah proses perubahan berlangsung jika masyarakat tetap memberi pengakuan terhadap eksistensi kekuasaan adat dan masih menghormati kewibawaan adat, maka posisi kelas sosial golongan Madika terus dipertahankan melalui hubungan-hubungan genealogik. Pada tahap inilah perkembangan secara bertahap terbentuknya klen-klen dominan di tanah Kaili, jika sekiranya penghormatan masyarakat terhadap kepemimpinan adat masih ada maka penghormatan tersebut mutlak menjadi hak golongan Madika. Kewibawaan adat tersebut kemudian memberi pengaruh besar terhadap posisi mereka pada puncak-puncak status sosial dalam startifikasi masyarakat Kaili. Tokohtokoh sentral dalam lembaga sosial politik yang merupakan golongan Madika membutuhkan kewibawaan nilai-nilai kepemimpinan adat karena dapat memberikan keuntungan bagi personifikasi mereka sebagai pemimpin yang berasal dari klen dominan. Pada masa kini posisi sosial golongan Madika yang berada pada puncak-puncak status sosial masih cukup signifikan menjadi dasar pertimbangan untuk mengisi posisi yang ada pada organisasi masyarakat dan lembaga politik juga termasuk pada lembaga pemerintah dan organisasi perkumpulan.

Dominasi klen dapat meningkatkan lebih besar rekruitmen perempuan anggota klen dominan untuk menjadi aktifis organisasi dengan hanya mengandalkan hubungan genealogik dalam satuan kekerabatan yang 
dimiliki. Dengan memperoleh jabatan yang strategik mereka dapat memperoleh akses terhadap kegiatan yang diargumentasikan sebagai kegiatan organisasi. Status perempuan yang berasal dari klen dominan ini menjadikan mereka dikenal luas dalam hubungan antar organisasi dan interaksi dengan lembaga pemerintahan. Posisi mereka sebagai orang dekat dengan pimpinan organisasi yang juga berlatar belakang klen dominan yang sama membuat mereka memperoleh kepercayaan untuk mengkomunikasikan kepentingan organisasi dan kebijakan pimpinan mereka terhadap pihak lain.

Besarnya kekuatan dominasi klen untuk memberikan peran pada perempuan untuk berpartisipasi secara politik, kenyataannya memiliki beberapa kelemahan. Perempuan dari klen dominan dengan kapasitas yang dimiliki mendapat keistimewaan untuk masuk dengan mudah dalam struktur organisasi terutama pada posisi-posisi strategik. Proses ini kadangkala mengabaikan mekanisme selektifitas, sehingga sebagian besar mereka yang terekrut atau terlibat relatif sedikit jumlahnya dengan tingkat pendidikan yang memadai. Demikian juga kompetensi organisasi yang mereka miliki relatif sangat terbatas bahkan sama sekali tidak dapat terartikulasi dengan baik dalam aktivitas organisasi.

\section{Daftar Kepustakaan}

Abdullah, Muhammad Djarudin. 1975. Mengenal Tanah Kaili. Palu : Badan Pengembangan Pariwisata Sulawesi Tengah.

Koentjaraningrat. 1981. Beberapa pokok Antropologi Sosial. Jakarta : Dian Rakyat.

Masyhuda, Mashudin. 1982. Mengenal Sulawesi Tengah. Palu : Yayasan Kebudayaan Sulawesi Tengah.

Zuhro, Siti R. 2009. Demokrasi Lokal: Peran Aktor Dalam Demokratisasi.

Yogjakarta:Ombak http://www.komunitasdemokrasi.or.id/article /Memperkuat.pdf. diakses pada tanggal 09/2002

http://www.jpnn.com/read/2011/03/11/864 05/Politik-Kekerabatan-Membajak-

Demokrasi diakses pada tanggal 12/9/2011

http://ellyasa.blogspot.com/2008/08/aromapolitik-kekerabatan.html- diakses pada tanggal 15/9/2011

http://ellyasa.blogspot.com/2008/08/ op. cit.di akses pada tanggal 12/9/2011, 